ORIGINAL ARTICLE

\title{
Characteristic of Referral Patients With Severe Preeclampsia In Surabaya
}

\author{
Myrna Evanda Adeline ${ }^{1}$, Muhammad Ardian Cahya Laksana ${ }^{2 *}$, Atika $^{3}$ \\ ${ }^{1}$ Faculty of Medicine, Universitas Airlangga, Surabaya, Indonesia \\ ${ }^{2}$ Department of Obstetrics and Gynecology, Faculty of Medicine, Universitas Airlangga - Dr. Soetomo General Hospital, \\ Surabaya, Indonesia \\ ${ }^{3}$ Departement of Public Health and Preventive Medicine, Faculty of Medicine, Universitas Airlangga, Surabaya, Indonesia
}

\author{
A R T I CLE INFO \\ Article history: \\ Received 30 April 2018 \\ Accepted 30 Mei 2018 \\ Available online 30 April 2018 \\ Keywords: \\ Severe preeclampsia, \\ Referral patient, \\ Maternal. \\ *) Corresponding author: \\ m.ardian@fk.unair.ac.id
}

Received in revised form 17 Mei 2018

\begin{abstract}
A B S T R A C T
Introductions: Preeclampsia is a hypertensive disorder of a pregnancy that remains major maternal mortality in developing country. Severe preeclampsia needed an advanced medical treatment since it could cause life treathening condition for both mother and fetus. Aims: The purpose of this research was to understand and got the profile of the age, parity, complication, delivery method, referral pathway, age of pregnancy, birth weight, and Apgar score of baby from pre-eclamptic mother in dr. Soetomo General Hospital during 2011.

Methods: This research is a retrospective-descriptive research which observed the age, parity, complication, delivery method, referral pathway, age of pregnancy, birth weight, and Apgar score of baby from preeclampsia mother in Dr. Soetomo Hospital Surabaya. All data was recorded and analyzed descriptively.

Result: The number of patients who met the inclusion criteria were 239 patients. Patient's age were distributed unimodally with a peak at productive age. Most of patients had previous history of pregnancy. Pulmonary edema was the most common cause of maternal complication and intra uterine fetal death was the most common cause of fetal complication. Most delivery were performed in Sectio Caesaria method. Almost all cases was direct refferal cases from other medical services. Then most of cases was reaching aterm periode. Most of babies were born with body weight $\geq 2500$ gram. And based on Apgar score the babies were well adapted.

Conclusions: Most of the patients with severe preeclampsia referrals were referred from a health care setting, only a small percentage of women were referred to relay. Most of severe preeclampsia occured in women with their gestational age has reached 37 weeks.
\end{abstract}

\section{Introduction}

Indicators of health and well-being are marked by maternal mortality rate or (MMR/AKI), infant mortality rate (IMR/AKB), and life expectancy (UHH). ${ }^{1}$ It is estimated that every day 800 women die during pregnancy and childbirth, 99\% occur in developing countries with causes that can be avoided. AKI in developing countries is estimated to be 240 per 100,000 live births, whereas in developed countries 16 per 100,000 live births. ${ }^{2}$

The greatest risk of maternal mortality is childbirth below 15 years and complications during pregnancy and childbirth. ${ }^{3}$ In Asia alone, childbirth complications that caused maternal mortality include bleeding (30.8\%), anemia (12.8\%), sepsis (11.6\%), severe preeclampsia (9.4\%) and hypertension (preeclampsia/eclampsia) (9.1\%). ${ }^{4}$ According to SDKI data in 2007, MMR in Indonesia reached the highest in ASEAN by 228 per 100,000 live births. Indonesia's maternal mortality rate is still far from the Millennium Development Goals (MDGs) number 5 of reducing MMR up to 102 per 100,000 live births by $2015 .{ }^{5}$

Preeclampsia-eclampsia contributed significantly to MMR in Indonesia on average $12 \% .{ }^{6}$ Maternal mortality from preeclampsia-eclampsia in East Java was reported

Biomolecular and Health Science Journal. All rights reserved.

Available at https://e-journal.unair.ac.id/BHSJ ; DOI: 10.20473/bhsj.v1i1.8219 
to be $117(28.2 \%)$ of 414 maternal deaths in 2007. In dr. Soetomo General Hospital, this disease is the cause of maternal moratlity number one over the years with number followed 57\% (1999), 54\% (2000), 58\% (2001), $48 \%$ (2002), $45 \%$ (2006) and $60 \%$ (2007). ${ }^{7}$

Preeclampsia can cause death because preeclampsia can be followed by some comorbid risks. For infants, the risk includes Intrauterine Growth Retardation (IUGR), mortality, premature birth that will lead to complications and disability. The risks for women include seizures (eclampsia), kidney failure, pulmonary edema, stroke, and death. ${ }^{8}$

Deaths in infants and mothers due to severe preeclampsia can be avoided by performing a good Referral System (RS) which is better planning and timely referral to a health facility that has management capabilities for obstetric and newborn emergencies. The reason why severe preeclampsia needs to be referred is that severe preeclampsia can lead to serious consequences for the mother, fetus, or both because it can develop into eclampsia and death.

The general objective of this study was to determine the description of maternal factors (age, number of parity, complications, mode of delivery, and gestational age), referral factors, and infant factors (BBL and Apgar values) in referral patients due to severe preeclampsia in dr. Soetomo General Hospital (RSUD Dr. Soetomo) Surabaya, Indonesia in 2011.

\section{Methods}

This research used descriptive research type with retrospective research design from medical record of preeclampsia patients in Department of Obstetrics and Gynecology RSUD Dr. Soetomo Surabaya in the period January 1, 2011 until December 31, 2011. Total sampling was used to retrieve the data. The data used in this study include age, number of parity, complications, mode of delivery, referral pathway, gestational age, infant birth weight, and infant Apgar score.

\section{Results}

The number of all severe preeclampsia patients recorded in the medical book of the Inpatient Installation Room (IRNA) Merak RSUD Dr. Soetomo in 2011 was 289 patients, 241 of them or $84 \%$ were referral patients. Data which met the inclusion criteria was 239 or $83 \%$ of all severe preeclampsia patients treated in IRNA Merak and $99 \%$ from of all referral patients due to severe preeclampsia (Table 1 and 2).

Table 1 Characteristics of referral patients with severe preeclampsia

\begin{tabular}{ccc}
\hline Age (years) & & \\
\hline$\leq 16$ & 3 & $1 \%$ \\
\hline $17-34$ & 175 & $73 \%$ \\
\hline$\geq 35$ & 61 & $26 \%$ \\
\hline Parity & & \\
\hline
\end{tabular}

\begin{tabular}{|c|c|c|}
\hline Primipara & 98 & $41 \%$ \\
\hline Multipara & 141 & $59 \%$ \\
\hline \multicolumn{3}{|l|}{ Complications } \\
\hline Yes & 47 & $20 \%$ \\
\hline No & 192 & $80 \%$ \\
\hline \multicolumn{3}{|l|}{ Complications } \\
\hline HELLP Syndrome & 8 & $18 \%$ \\
\hline Lung Edema & 18 & $39 \%$ \\
\hline Arrest & 10 & $21 \%$ \\
\hline IUGR & 3 & $6 \%$ \\
\hline IUFD & 7 & $14 \%$ \\
\hline abruptio placentae & 1 & $2 \%$ \\
\hline \multicolumn{3}{|l|}{ Delivery mode } \\
\hline Section Caesaria & 129 & $54 \%$ \\
\hline Spontaneous & 86 & $36 \%$ \\
\hline Vaccum & 16 & $6,7 \%$ \\
\hline Forcep & 6 & $2,5 \%$ \\
\hline Cunam & 1 & $0,4 \%$ \\
\hline Manual aid & 1 & $0,4 \%$ \\
\hline \multicolumn{3}{|l|}{ Referral pathway } \\
\hline$<2$ places & 236 & $99 \%$ \\
\hline$\geq 2$ places & 3 & $1 \%$ \\
\hline \multicolumn{3}{|l|}{ Referral origin } \\
\hline Hospital & 97 & $40,6 \%$ \\
\hline Puskesmas & 44 & $18,4 \%$ \\
\hline $\begin{array}{l}\text { Doctor of private } \\
\text { practice }\end{array}$ & 60 & $25,1 \%$ \\
\hline $\begin{array}{l}\text { Private midwife } \\
\text { practice }\end{array}$ & 33 & $13,8 \%$ \\
\hline Medical specialist & 2 & $0,8 \%$ \\
\hline $\mathrm{BPS} \rightarrow \mathrm{RS}$ & 2 & $0,8 \%$ \\
\hline $\begin{array}{l}\text { General doctor } \rightarrow \\
\text { Medical specialist }\end{array}$ & 1 & $0,4 \%$ \\
\hline \multicolumn{3}{|l|}{ Pregnancy age } \\
\hline Aterm & 186 & $74,1 \%$ \\
\hline Moderate preterm & 46 & $18,3 \%$ \\
\hline Very preterm & 12 & $4,8 \%$ \\
\hline Extremely preterm & 7 & $2,8 \%$ \\
\hline
\end{tabular}

Table 2 Characteristics of infants born to referral patients with severe preeclampsia

\begin{tabular}{lcc}
\hline Weights & & \\
\hline$\geq 2500$ gram & 158 & $62,9 \%$ \\
\hline $1500-2499$ gram (BBLR) & 68 & $27,1 \%$ \\
\hline $1000-1499$ gram (BBLSR) & 19 & $7,6 \%$ \\
\hline$<1000$ gram (BBLASR) & 6 & $2,4 \%$ \\
\hline Apgar score & & \\
\hline$\geq 7$ & 152 & $61 \%$ \\
\hline$<7$ & 99 & $39 \%$ \\
\hline Asphyxia (Apgar score < 7) & & \\
\hline Low-Medium & 38 & $38 \%$ \\
\hline Severe & 61 & $62 \%$ \\
\hline
\end{tabular}




\section{Discussion}

Age is one of the factors that influence the determination of the presence or absence of potential obstetric emergencies. $^{9}$ Age is also a risk factor for severe preeclampsia. Mother's age of more than 40 years is said to increase the risk of preeclampsia. ${ }^{10}$ In this study, severe preeclampsia was found in the 17-34 age group of $175(73 \%)$ of cases, unlike the assertion that age over 40 years increases the risk of preeclampsia. This may be due to the general age of the mother who mostly experienced pregnancy and delivery in the age of 17 to 34 years old, so that the number of severe preeclampsia was mostly found at that age too.

Parity is also one of the most important risk factors for severe preeclampsia. Preeclampsia has long been considered the first pregnancy complications. A previous normal pregnancy history is considered a factor that lowers the risk of preeclampsia. However, the protective effect of this multiparity disappears if the husband changes. The risk of preeclampsia in the second pregnancy increased with increasing maternal age and intermittent intervals. ${ }^{10}$ In this study it was found that more severe preeclampsia was found in women with previous or multiparous pregnancies, as many as 141 (59\%) cases. While severe preeclampsia on primipara mother group was less found which only 98 (41\%) cases. This facts did not render that the preeclampsia primipaternity statement invalid because there are many other factors involved that were not taken into account in this study, such as husband factors, maternal age at second or third pregnancy, and the interval of previous pregnancy. The data in this study showed only paternity distribution in referral patients due to severe preeclampsia.

Based on the data obtained, complications derived from mothers with the highest number of pulmonary edema amounted to $18(39 \%)$ cases. The incidence of pulmonary edema in these patients with severe preeclampsia is much higher than Soedarmadi's findings in RSUD Dr.Soetomo which stated that the prevalence of pulmonary edema in preeclampsia-eclampsia sufferers was $2.3 \%{ }^{6}$. This may be explained because in this study only severe preeclampsia cases belong to inclusion category, whereas eclampsia was not.

The mode of delivery with Sectio Caesaria (SC) is generally based on Bishop's score with poor prognosis, fetal malpresence, fetal distress, and bleeding, not solely because of preeclampsia. In this study it was found that the method of delivery performed in referral patients due to severe preeclampsia by Sectio Caesaria was 129 $(54 \%)$, spontaneous was $86(36 \%)$, and $24(10 \%)$ through the pull of vaccum, forcep, cunam, and manual aid.

Almost all referral cases $(99 \%)$ did not go through the relay path, indicating a healthcare provider's sensitivity to the existence of an emergency obstetrician (AGDO) so that a timely reference was required and not extending the referral route by immediately referring patients to a central hospital, in this case is RSUD Dr. Soetomo.

Pregnancy age in which severe preeclampsia occurs is at term, which the pregnancy period has reached 37 weeks. This complications generally occurs in the third trimester of pregnancy, but can also be found in the second trimester. ${ }^{11}$ In this study, $186(74.1 \%)$ of the fetus had reached the age of term, corresponding to the previous theories.

In this study it was found that most of the 158 (62.9\%) fetuses who were born to mothers with severe preeclampsia have had adequate birth weight. The smallest birth weight was 300 grams and the greatest birthweight was 4500 grams. In this study we also found 9 mothers who had HELLP syndrome.

Based on the Apgar score, 152 (61\%) fetuses had a score of $\geq 7$ which means the fetus was in good condition, $38(15 \%)$ of fetuses had score of 4-6 which means the fetus was in a medium depression condition, and 61 (24\% the fetus was severely depressed. Most fetuses have a good Apgar score because most of them were born after reaching term.

\section{Conclusion}

The highest age group of patients with severe preeclampsia referrals were 17-34 years with a history of multiparas. The most severe complications of preeclampsia that occur in the mother are pulmonary edema, followed by arrest and HELLP syndrome, whereas the most common fetal complications were IUFD, followed by IUGR and placental abruption. The most common mode of delivery was Sectio Caesaria (SC), followed by spontaneous birth, birth aided by the pull of vaccum, forcep, cunam, and manual aid. Most of the patients with severe preeclampsia referrals were referred from a health care setting, only a small percentage of women were referred to relay. Most of severe preeclampsia occured in women with their gestational age has reached 37 weeks. Infants who were born to preeclamptic referral patients were mostly born with a weight of $\geq 2500$ gram and have an Apgar score of $\geq 7$ (good).

\section{Conclusion}

The author stated there is no conflict of interest

\section{References}

1. Aziz A, Khan FA and Wood G. Who is excluded and how? An analysis of community spaces for maternal and child health in Pakistan. Health Res Policy Syst. 2015; 13: Suppl: 1:56.

2. WHO. Maternal Mortality. Geneva: World Health Organization, 2012.

3. Yussif AS, Lassey A, Ganyaglo GY, Kantelhardt EJ and Kielstein H. The long-term effects of adolescent pregnancies in a community in Northern Ghana on subsequent pregnancies and births of the young mothers. Reproductive health. 2017; 14: 178 . 
4. Gunawardena N, Bishwajit G and Yaya S. Facility-Based Maternal Death in Western Africa: A Systematic Review. Frontiers in public health. 2018; 6: 48.

5. Wardhani AK. Angka kematian ibu di Indonesia tertinggi seASEAN. 2012

6. Lestaluhu A and Dachlan EG. Hubungan antara kadar albumin serum, riwayat hipertensi kronis, kadar kreatinin serum, infeksi, dan paritas dengan kejadian edema paru pada penderita preeklampsia berat -eklampsia di RSU dr.Soetomo Surabaya. Fakultas Kedokteran. Surabaya: Universitas Airlangga, 2006.

7.Dachlan EG. Karakteristik preeklampsia-eklampsia Indonesia sebagai penyebab utama kematian ibu bersalin. Pidato Pengukuhan Jabatan Guru Besar Ilmu Kebidanan dan
Penyakit Kandungan Fakultas Kedokteran Universitas Airlangga. Surabaya2008.

8. Spracklen CN, Smith CJ, Saftlas AF, et al. Genetic predisposition to elevated levels of $\mathrm{C}$-reactive protein is associated with a decreased risk for preeclampsia. Hypertension in pregnancy. 2017; 36: 30-5.

9. Rochjati P. Bunga rampai obstetri dan ginekologi sosial. Jakarta: Yayasan Bina Pustaka Prawirohardjo, 2005.

10. Pare E, Parry S, McElrath TF, Pucci D, Newton A and Lim $\mathrm{KH}$. Clinical risk factors for preeclampsia in the 21 st century. Obstetrics and gynecology. 2014; 124: 763-70.

11. Saiffudin AB. Buku panduan pelayanan kesehatan maternal dan neonatal. Jakarta: Yayasan Bina Pustaka Sarwono Prawirohardjo, 2002. 